\section{DIARY}

The Dental Therapist: free lecture Dates and venues:

8 April 2013, 5.45-7.45 pm,

Henry Schein Showroom,

Birstall, Leeds

15 April 2013, 5.45-7.45 pm,

Henry Schein Showroom, Cardiff

18 April 2013, 6-8 pm, Henry Schein

Showroom, Marble Arch, London

Email: info@dentaltherapistsrock.co.uk

www.dentaltherapistsrock.co.uk

MC Repairs Limited Free Open Day Date: 27 April 2013

Venue: 11 Avroe Crescent,

The Pavilions, Blackpool

Telephone: 01253404774

www.mcrepairs.co.uk

British Dental Conference

Ct Exhibition 2013

Date: 25-27 April 2013

Venue: ExCel London

www.bda.org/conference

ADI 2013 Congress

Date: 1-3 May 2013

Venue: Manchester Central

Convention Complex

www.adi.org.uk/congress2013

Preparation for the Diploma in Implant Dentistry

Date: 10 May 2013

Venue: The Royal College of Surgeons

of Edinburgh

www.rcsed.ac.uk/education/

courses-and-events/coursedetails.

aspx?diaryld $=1118$

Dental Sedation Teachers

Group Symposium

Date: 14 May 2013

Venue: Millennium Stadium, Cardiff

www.dstg.co.uk

\section{Scottish Dental Show}

Date: 16-17 May 2013

Venue: Hampden Park, Glasgow

www.scottishdentalshow.co.uk

Premium education on

digital dentistry:

Sirona Imaging User Days

Date: 7 June 2013

Telephone: 08450715040

Email:info@sironadental.co.uk

Association for Dental Education in

Europe (ADEE) meeting

Date: 28-31 August 2013

Location: Birmingham

www.birmingham.ac.uk/adee2013

\title{
EVERLASTING SMILES FOR NORTH WALES
}

On 17 January this year Welsh Health Minister, Lesley Griffiths, launched a new oral health service for older people living in Flintshire, North Wales.

The 'Gwên am Byth' or 'Everlasting Smiles' initiative is designed to improve the dental and oral health of people living in residential care homes and a purpose-designed mobile dental unit has been provided that will visit establishments across the county, bringing specialist care to patients.

The launch took place at Holywell Community Hospital, where the Minister officially unveiled the mobile dental unit and met the dental team who

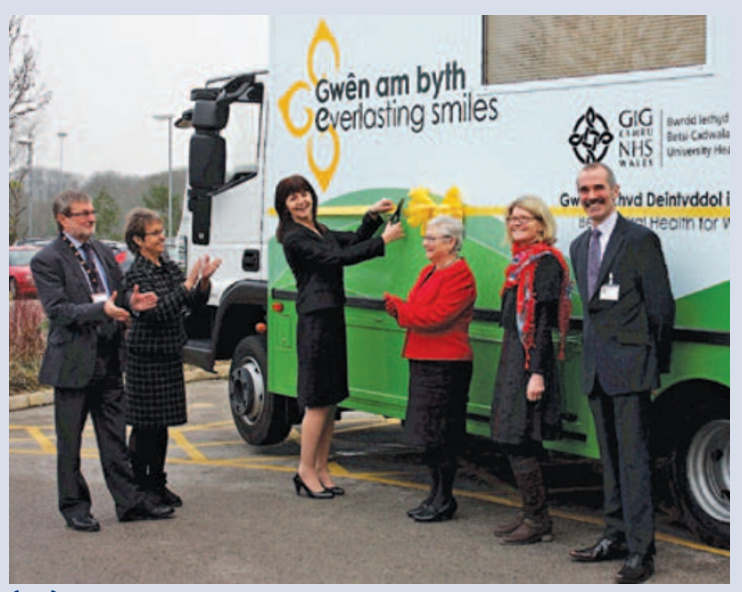

(I-r) Professor Merfyn Jones, Chairman, Betsi Cadwaladr University Health Board; Mary Burrows, Chief Executive, Betsi Cadwaladr University Health Board; Welsh Health Minister, Lesley Griffiths; Sandy Mewies AM; Dr Michele Seager, Assistant Clinical Director/Specialist in Special Care Dentistry, Betsi Cadwaladr University Health Board; Dr Paul Coleman, Specialist in Special Care Dentistry, Betsi Cadwaladr University Health Board will be providing the service. The Minister, accompanied by Dr Sandra Sandham, Director of Dental Public Health, also visited the three surgery dental facility at the hospital which includes one surgery with a wheelchair recliner that enables patients to be treated without having to transfer to a dental chair.

Dr Michele Seager, Assistant Clinical Director North Wales Community Dental Service and a specialist in special care dentistry said: 'This programme has grown from observing a very real clinical need emerging over a number of years, whereby older residents were not getting the care support they needed to maintain their mouths in health, and were having difficulties in accessing appropriate care. [...] It is all about maintaining dignity, freedom from pain and discomfort, and the confidence to socialise.'

The Gwên am Byth team includes an oral health educator as well as a specialist dentist and a dental nurse, who will provide help and advice on oral care to both residents and staff.

\section{LIVERPOOL PRACTICE RAISES AWARENESS OF TOOTH LOSS}

Ollie and Darsh, a private cosmetic dentistry provider in Liverpool specialising in dental implants, have created an infographic designed to spread awareness of the causes of tooth loss for adults and the possible solutions.

It is hoped that the infographic instructs and advises the public about dental healthcare and the simple processes by which dental implants can be obtained.

The infographic can be viewed at www.ollieanddarsh.co.uk/blog/implants/ what-to-do-when-you-lose-a-tooth.

\section{BDA BULLETIN}

- The BDA has greeted the confirmation that primary care dentists will initially be exempted from licensing by Monitor, the NHS economic regulator, as a victory for common sense. The exemption will be reviewed in 2016/2017.

- The BDA Benevolent Fund has launched a photo competition with the theme 'Be Active'. Entrants should send an A4 or 10" $\times 8$ " photographic print to BDA Benevolent Fund Photo Competition, 64 Wimpole Street, London, W1G 8YS or email as a jpeg file (as large as possible and 300 dpi resolution) to dentistshelp@ btconnect.com. Entries will be exhibited at the British Dental Conference and Exhibition in April. The winner will be announced at the Fund's AGM on 21 June.

- The BDA Benevolent Fund is holding the first ever BDA Charity Auction during the drinks reception at the British Dental Conference and Exhibition, at 6 pm on 25 April. Delegates will be able to bid for dental equipment supplies and services, or unique, luxury experiences. 